\title{
Influence of informal employment on investments into human capital
}

\author{
Tatiana K. Blokhina, \\ Department Finance and Credit of RUDN University. \\ ul. Miklukho-Maklaya 6, Moscow, Russia, 117198 \\ blokhina_tk@rudn.university
}

\author{
Oksana A. Karpenko \\ Department Finance and Credit of RUDN University. \\ ul. Miklukho-Maklaya 6, Moscow, Russia, 117198 \\ karpenko_oa@rudn.university
}

\begin{abstract}
Informal employment is a factor of the quality of the human capital. The article includes a research of informal employment, which is considered to be an independent phenomenon. Earlier it was analyzed without estimating its influence on the development of the human capital. Unlike the settled points of view in the article, informal employment is estimated as the negative factor reducing the main investments into the human capital formed at the expense of social funds. Dependence of these funds on growth rates of informal employment is shown. Normalization of a situation is in a reduction of informal employment that assumes using the mechanisms of institutionalization of informal employment by means of patents and licenses for certain kinds of activity, which have to promote a reduction of a possibility of using work without the corresponding registration.
\end{abstract}

Keywords - human capital, informal employment, investments, sources of investments, social funds.

\section{INTRODUCTION}

Russian economy has new challenges and approaches to management of employment in the Russian labor market. It provokes a need in the analysis of arising tendencies for development of the labor relations which radically change relationship between employers and workers, raise them to a new independent level.

Recently in the Russian labor market, such forms of relationship as remote employment when the worker is on access remote from the employer, or freelance within and the worker finds volume of work were widely adopted. The worker in this case agrees with the employer and determines the price of the work. All this became possible due to distribution of the computer technologies allowing one to carry out relationship between the worker and the employer without direct contact on the Internet. There are widely adopted such forms of employment as temporary, incomplete, informal on the terms of which more and more workers agree.

Within 2009-2017, the Russian labor market developed at rather low unemployment rate $-5.0-5.5 \%$ of the general level. It provided generally all the expenses of a small gain of the total number occupied in economy and also had a considerable distribution of informal forms of employment which had no legal registration of the labor relations. Earlier employment was understood as hired labor in the organizations of all forms of ownership. Nowadays, this concept is extended due to inclusion of participation of workers in a business activity, a household, and many other occupations [2].

The analysis of distribution of not registered forms of employment shows that they take place in spheres of business, such as agriculture, construction, retail trade, i.e. in spheres where work does not give in to full account [1]. Work without the issued relations widely is applied in farms of willows personal subsidiary farm. In 2017 the number of informally busy was estimated at 14.3 million people, and the number of self-employed - 4 million people.

Growth of informal employment is a negative factor for the Russian economy. Its negative influence is shown in a number of the problems both for economy in general, and for workers of this sphere:

- use of informal work allows employers to save on production modernization that slows down introduction of new technologies, gives a poor quality of production and services of this sector;

- - economy on labor costs brings a concealment of income from the taxation and obligatory payments into off-budget funds; therefore the state budget loses a considerable part of income.

- - the workers engaged in informal economy has no real social guarantees and control apart from the conditions of their work;

- - the irregular nature of employment in the informal sector influences quality of labor, leading to partial loss of qualification and professional skills;

- - use of workers in the informal sector reduces quality of the human capital in Russia.

In this regard, the special relevance is received by a research of informal employment and its influence on the human capital that demands a certain accounting and development of the state regulation policy of employment in the Russian labor market.

Quality of the human capital becomes one of the main indicators of effective development of economy in the third millennium [3]. The concept "human capital" includes the saved-up stock of knowledge, skills and competences which are possessed by each person for the purpose of their use as a 
source of future income [4]. As any capital, it needs investments in the person, which represent one of forms of distribution of resources in time when the real benefits in this exchange influence the future [5].

Experts of OECD have offered the definition of the human capital reflecting all aspects of the process of investment into people. The human capital represents "knowledge, skills, abilities and abilities embodied in people, allowing them to create personal, social and economic welfare" [12]. This interpretation of the human capital allows allocating the main directions of process of investment, which concentrate on development of education, formation of production skills, maintenance of health, employment.

In 2012 Kapelyushnikov [11] has carried out calculations of the human capital of Russia on the basis of using a method of Jorgenson - Fraumeni [8] for the periods of 2002 and 2010 and has shown that the stock of the human capital of Russia in 2010 has made more than 600 trillion rub, and per capita - 6 million rubles. This indicator was 13 times above GDP of Russia and 5.5 times exceeded the volume of the physical capital. Having carried out comparison with the period of 2002 in real terms, R. Kapelyushnikov has proved that the volume of the human capital has grown twice throughout these years. Growth has happened at the expense of the following factors: decrease in mortality rate, increase in educational activity of youth, gain of the real wage, reduction of unemployment and improvement of a situation with employment [6].

There is a stratification of employment into formal and informal [9], but the situation with employment changes. The positive dynamics caused by steadily low unemployment rate takes place and there is a growth of the informal (unregistered) employment. From 2012 to 2015, the annual gain of workers in the sphere of informal employment makes 3-5\%. In 2015 the number of informally busy has grown to 14.8 million people that makes $20.5 \%$ of the busy population of Russia [11].

Such situation has negative consequences for investment into the human capital. It reduces volumes of the main sources for investments - the Pension Fund of the Russian Federation, Social insurance fund and Fund of obligatory medical insurance, which receive fewer payments owing to existence of a big number of the unregistered workers who are receiving the "shadow" salary and not carrying out any payments in the specified funds.

Besides, informal employment exerts negative impact on quality of the human capital. Existence of the constant proposal of cheap labor of low qualification and ready to work for low wage promotes fixing of primitivization of production, decline in production of work, low technological safety of works that reduces investments into development of the workers occupied in the informal sector of economy.

Thus, growth of informal employment in economy of Russia exerts direct impact on investments into the human capital in this connection there is a need for detection of this dependence for the purpose of development of methods of its regulation.

\section{EMPIRICAL ANALYSYS}

As an analysis basis, we have taken data of the Russian statistical agency on a number of informally employed people in economy and data on dynamics of payments in the Pension Fund of the Russian Federation (PFRF), the Social Insurance Fund (SIF) and the Fund of obligatory medical insurance of the Russian Federation (Federal Compulsory Health Insurance Fund) during 2004-2015 (Tab. 1).

TABLE 1. DYNAMICS OF THE NUMBER OF INFORMALLY EMPLOYED POPULATION AND PAYMENTS IN RPF, THE SOCIAL INSURANCE FUND AND FEDERAL COMPULSORY HEALTH INSURANCE FUND

\begin{tabular}{|c|c|c|c|c|}
\hline Year & $\begin{array}{c}\text { Informally } \\
\text { busy, } \\
\text { one thousand } \\
\text { people }\end{array}$ & $\begin{array}{c}\text { Payments to } \\
\text { the Social } \\
\text { Insurance } \\
\text { Fund, } \\
\text { billion } \\
\text { rubles. }\end{array}$ & $\begin{array}{c}\text { Payments to } \\
\text { Federal } \\
\text { Compulsory } \\
\text { Health Insurance } \\
\text { Fund, } \\
\text { billion rubles. }\end{array}$ & $\begin{array}{c}\text { Payments in } \\
\text { Russian } \\
\text { pension fund } \\
\text { (RPF), } \\
\text { billion rubles. }\end{array}$ \\
\hline $\mathbf{2 0 0 4}$ & 11343 & 159276 & 68130 & 1015800 \\
\hline $\mathbf{2 0 0 5}$ & 12518 & 186672 & 83003 & 1349601 \\
\hline $\mathbf{2 0 0 6}$ & 12601 & 218913 & 125524 & 1637580 \\
\hline $\mathbf{2 0 0 7}$ & 12931 & 295368 & 157817 & 1946817 \\
\hline $\mathbf{2 0 0 8}$ & 13837 & 360476 & 162621 & 2730172 \\
\hline $\mathbf{2 0 0 9}$ & 13382 & 440046 & 126562 & 3222649 \\
\hline $\mathbf{2 0 1 0}$ & 11482 & 463777 & 101844 & 4610084 \\
\hline $\mathbf{2 0 1 1}$ & 12922 & 558595 & 348437 & 5255643 \\
\hline $\mathbf{2 0 1 2}$ & 13600 & 630784 & 966542 & 5890364 \\
\hline $\mathbf{2 0 1 3}$ & 14096 & 603499 & 1101352 & 6388390 \\
\hline $\mathbf{2 0 1 4}$ & 14387 & 569825 & 1250545 & 6159055 \\
\hline $\mathbf{2 0 1 5}$ & 14827 & 541282 & 1573543 & 7126634 \\
\hline
\end{tabular}

Source: calculated according to Rosstat: Economic activity of the population. Rosstat, 2016. Electronic resource: http://www.gks.ru/bgd/regl/b16_61/Main.htm; http://www.gks.ru/free_doc/new_site/finans/gfin_tab1.htm

Comparison of the specified data has shown that an increase in growth rates of informal employment is followed by a decrease in growth rates of receipts in social funds through an interval of 1-2 years. Most visually this communication was shown in 2008 when rate of a gain of informally busy has grown to $7.0 \%$, fall of the income of social funds was reduced by the next year: in RPF - twice, in Federal Compulsory Health Insurance Fund - by $22.17 \%$. The similar tendency was shown also during 2013-2015: rate of a gain of informal employment has made during this period 2$3.6 \%$ while falling of rates of receipts in the Social Insurance Fund - 4-5.57\%, RPF - 3.62\%, Federal Compulsory Health Insurance Fund - 12 times.

\section{MODEL OF MULTIPLE REGRESSION.}

For development of policy of regulation of informal employment, it is necessary to reveal the system of the interrelations providing its distribution. The correlation of forms of employment with the social system of the state plays an important role in ensuring development of the human capital.

If there is a weak link in the system of public administration communication between control of labor 
market and development of informal kinds of employing workers, the opportunities for involvement of labor to the shadow sector of economy will increase. Existence of the shadow sector of economy, which is dropping out of the sphere of state regulation, is defined by the size and structure of the informal sector.

Development of various forms of informal employment concerns two main consequences for economy. On the one hand, informal employment concerns the poorest segments of the population which need social protection, and the informality of the labor relations deprives them of this protection. On the other hand, the state does not receive a considerable part of taxes and payments in social off-budget funds which are paid by workers and their employers. Thereby the opportunities for social protection are reduced in these segments of the population.

In this connection, it is necessary to investigate interrelation between workers occupied in the informal sector and change of a stream of payments in the off-budget funds providing development in Russia of the human capital.

The purpose of multiple linear regression is creation of a linear model of communication between a set of continuous predictors and a continuous dependent variable. There are always several factors that influence any economic indicator.

The correlation and regression analysis analyze the forms of communication establishing quantitative ratios between random variables of the studied process. The social and economic forecasting of this method is applied to creation of the conditional forecasts and forecasts based on assessment of steady relationships of cause and effect.

For the characteristic of the real interrelations, which are shown generally during many observations, the statistics resorts to studying of stochastic dependences. Such communication corresponding to an average value of a productive indicator is called correlation. "Correlation" in translation from late Latin (correlation) means "ratio", "compliance", "interrelation", "interdependence". It is a change of an average value of a productive sign caused by the change of values of factorial signs.

The correlation matrix is a matrix of coefficients of correlation of several random variables with nonzero dispersions. We made it for our variables.
TABLE 2. THE CORRELATION MATRIX

\begin{tabular}{|c|c|c|c|c|}
\hline & $\begin{array}{l}\text { Inform } \\
\text { ally } \\
\text { busy }\end{array}$ & $\begin{array}{l}\text { Payme } \\
\text { nts to } \\
\text { the } \\
\text { Social } \\
\text { Insura } \\
\text { nce } \\
\text { Fund }\end{array}$ & $\begin{array}{c}\text { Payments } \\
\text { to Federal } \\
\text { Compulsor } \\
\text { y Health } \\
\text { Insurance } \\
\text { Fund }\end{array}$ & $\begin{array}{c}\text { Payme } \\
\text { nts in } \\
\text { RPF }\end{array}$ \\
\hline Informally busy & 1 & & & \\
\hline $\begin{array}{c}\text { Payments to the } \\
\text { Social Insurance } \\
\text { Fund }\end{array}$ & 0,6298 & 1 & & \\
\hline $\begin{array}{c}\text { Payments to } \\
\text { Federal } \\
\text { Compulsory } \\
\text { Health Insurance } \\
\text { Fund } \\
\end{array}$ & 0,7958 & 0,7294 & 1 & \\
\hline Payments in RPF & 0,6675 & 0,9504 & 0,8637 & 1 \\
\hline
\end{tabular}

From table 2 we can see a high value of correlation is observed between informally busy and Payments to Federal Compulsory Health Insurance Fund. The correlation is less between informally busy and payments to the RPF and Payments to the Social Insurance Fund. It means that these funds lose a great deal of possible payments.

In table 3 , the regression analysis estimates the general quality of the model: its reliability on significance value of the criterion of Fischer - $p$ which has to be less than 0.05 (the line Regression, the Importance of $\mathrm{F}$ column). R-square value describes an accuracy degree process model (the second line from above in the table of Regression statistics). Further, we define values of coefficients of the model. They are from the table in column coefficients - in the line Y-crossing - the free member, in lines of the corresponding variables - values of coefficients at these variables. R-value is given reliability of difference of the corresponding coefficients from zero in a column.

In case $p>0.05$, the coefficient can be considered as zero. It means that the corresponding independent variable practically does not influence a dependent variable and the coefficient can be cleaned from the equation.

Reliability on the significance value of the criterion of Fischer (the Importance of F) much less than 0.05 means that the model is significant.

The description accuracy degree process model of the Rsquare is equal to 0.72 that speaks about high precision of approximation (the model describes the process well) (Tab.3). 
TABLE 3. REGRESSION STATISTICS

\begin{tabular}{|c|c|}
\hline Regression statistics & \\
\hline Multiple $\boldsymbol{R}$ & 0,849251821 \\
\hline R-square & 0,721228656 \\
\hline Rated $\boldsymbol{R}$-square & 0,616689402 \\
\hline Standard error & 668,1872167 \\
\hline Observations & 12 \\
\hline
\end{tabular}

Breusch-Godfrey serial correlation LM-test

Let us carry out the procedure of autocorrelation's check of any order in random errors of the regression in BreuschGodfrey serial correlation LM-test. This test is asymptotic (reliability of conclusions requires the large volume of selection). The test allows checking autocorrelation of any order using residuals (Tab. 4).

TABLE 4. RESIDUALS OF THE MODEL.

\begin{tabular}{|c|c|c|c|}
\hline $\begin{array}{c}\text { The } \\
\text { obser } \\
\text { vation }\end{array}$ & Predicted Y & Remains & $\begin{array}{c}\text { Standard } \\
\text { remains }\end{array}$ \\
\hline $\mathbf{1}$ & 12360,71857 & $-1017,718569$ & $-1,785997657$ \\
\hline $\mathbf{2}$ & 12347,87934 & 170,1206649 & 0,298545313 \\
\hline $\mathbf{3}$ & 12474,67184 & 126,3281567 & 0,221693697 \\
\hline $\mathbf{4}$ & 12885,67867 & 45,32132515 & 0,079534542 \\
\hline $\mathbf{5}$ & 12786,09917 & 1050,900826 & 1,84422931 \\
\hline $\mathbf{6}$ & 12910,32971 & 471,6702894 & 0,827735739 \\
\hline $\mathbf{7}$ & 11975,56996 & $-493,5699598$ & $-0,866167543$ \\
\hline $\boldsymbol{8}$ & 12805,23159 & 116,7684106 & 0,204917267 \\
\hline $\boldsymbol{9}$ & 14407,68937 & $-807,6893668$ & $-1,417416721$ \\
\hline $\mathbf{1 0}$ & 14168,46543 & $-72,46542715$ & $-0,127169816$ \\
\hline $\mathbf{1 1}$ & 14467,46976 & $-80,46976423$ & $-0,141216653$ \\
\hline
\end{tabular}

Source: made by the authors

An advantage of the test of Breush-Godfrey in comparison with Darbin-Watson test is that it is checked by means of the statistical criterion; meanwhile Darbin-Watson test contains a zone not of definiteness for values of statistics of $d$. Another advantage of the test is the possibility of generalization: the number of regressors can include not only the remains with $\log 1$, but also with $\log 2,3$ and $t$ of that allows one to reveal a correlation not only between next, but also between more remote observations.

The null hypothesis is a hypothesis of autocorrelation's absence in the model. To make a decision, the calculated test statistic is checked with the critical value for appropriate degrees n-2 of freedom and a 5\% level of significance. Using the information from table 1 , we determine if the sample correlation is significant at the $95 \%$ level of probability. For the sample data in Table 3, using residuals of the model while $\mathrm{n}=11$ at the $95 \%$ level of probability, the test statistic can be computed as 0.923657452 . That is less than the critical value of t-statistics 1.795884819. The test of Breush-Godfrey proved the null hypothesis of autocorrelation's absence in the model. Our research shows interrelation of growth rates of informal employment and the sizes of social funds that needs more careful accounting in social policy of the state.

\section{CONCLUSION.}

Thus, our research shows that a higher raise of informal employment leads to lower growth of receipts in social funds, which are the main source for investments into the human capital.

Wide circulation of informal employment is caused by existence of certain advantages of this form of the labor relations. The employers have greatest advantages by using informal forms of employment. They provide flexibility of workers depending on production cycles, seasonality, etc. Employers refuse official registration of their workers. It allows them to save on obligatory payments in the Pension fund and other social off-budget funds.

For workers a non-standard employment also has certain benefits. They can exploit flexible working hours, combine such work with study or other work. At the same time, a considerable part of informally busy workers includes such employment as an alternative to unemployment. Wide circulation of informal employment in the Russian economy is caused by absence of control of development of various forms of use of labor in the system of public administration. It creates a possibility of attraction of considerable number of workers to the informal sector of economy.

It is possible to allocate several reasons of development of the informal labor relations in economy.

First, as an incentive to growth of informal labor market the excess proposal of labor can take place. In this case, work in the informal sector is a standard of living.

Second, the low level of the salary in the formal sector influences growth of informal employment of several categories of citizens.

Third, weak state regulation of the labor relations also exerts impact on formation of informal employment. The population has an opportunity to work outside formal economy.

At the same time, informal employment makes ambiguous impact on labor market. On the one hand, such employment positively provides expansion of the general employment and assistance to increase in income of the population. On the other hand, it opens certain advantages to employers regarding business conditions. So, according to a number of researchers, among motives of leaving in informal employment the aspiration to earn and support or increase the standard of living $(35 \%)$ is on the first place. On the second hand, it is an aspiration of businessmen to decrease in costs and conceal taxable income (28\%). A considerably smaller one is the aspiration to filling at the expense of informally taken nonprestigious jobs (7\%), or more flexible use of labor $(2 \%)$. 
Results of various researches show that the state created high barriers of the introduction of businessmen on the market (bureaucratic barriers at business registration, the difficult taxation, high percent when crediting). For this reason, a considerable part of the Russian businessmen takes away the business to the shadow sector of economy. Therefore, simplification of conditions of business, liquidation of bureaucratic barriers is the key direction of essential reduction of scales of informal employment.

In this regard, it is possible to draw the following conclusion. Growth of informal employment makes uncomfortable conditions of business in Russia for businessmen.

Thus, the allocated reasons of growth of informal employment of dependence allow formulating a number of the directions of impact on development of this process that are as follows:

- preservation of policy of maintenance of growth of the salary in economy;

- improvement of conditions of business in Russia for self-employed persons regarding decrease in tax burden and simplification of the procedure of entry into business;

- improvement of the state supervision in the sphere of the labor relations

Informal employment arose as reaction to a series of negative measures, economic shocks and promoted some mitigation of the related expenses [13]. Growth of informal employment is not short-term anomaly and not the political miscalculation [10]. Informal employment allows avoiding payment of insurance premiums in off-budget funds (including on mandatory pension insurance) and an income tax. Evading from payment of these taxes and contributions, the organizations worsen social security of the employees.

The size of future pension of the working citizens, payment of sick-lists, including on pregnancy and childbirth, the sum of tax deductions depends on the size of the official salary when acquiring housing or costs of training of children and also all other investments into the human capital.

It makes a global, independent tendency, which requires carrying out in-depth scientific research, the analysis of their results, of development of the offers and practical measures capable to influence effectively the developing situation and to enter it into a framework of the Russian legislation.

Normalization of a situation is in the reduction of informal employment that assumes use of mechanisms of an institutionalization of informal employment by means of patents and licenses for certain kinds of activity, which have to promote reduction of a possibility of use of work without the corresponding registration. Also improvement of the tax system and simplification of accounting reports are necessary for stimulation of development of small business in Russia and raise investments into the human capital.

\section{References}

[1] S. Bernabe "Informal Employment in Countries in Transition: A Conceptual Framework", CASE Paper, 2002. https://core.ac.uk/download/pdf/7119222.pdf

[2] E. De Soto "The Mystery of Capital: Why Capitalism Triumphs in the West and Fails Everywhere Else". Finance and Development Vol 38, No. 1, March 2001.

[3] M. Carr, M.A. Chen "Globalization and the Informal Economy: How Global Trade and Investment Impact on the Working Poor?", ILO WP on the Informal Economy, vol. 2002/1.

[4] M. Castells "Information Age: Economy, Society and Culture", Vol. III. Cambridge, MA; Oxford, UK: Blackwell, 1998.

[5] M. Chen, R. Jhabvala, F. Lund "Supporting Workers in The Informal Economy: A Policy Framework" ILO WP on the Informal Economy, No. 2002/2.

[6] S. Clarke "Making Ends Meet in a Non_Monetary Market Economy" Centre for Comparative Labour Studies, and University of Warwick. Technical Report, 1999.

[7] M. Foley "Labor Market Dynamics in Russia". Economic Growth Center Discussion Paper No. 780. Yale University, 1997.

[8] D.W. Jorgenson, B.M. Fraumeni "The Output of the Education Sector", Z.Griliches (ed.). Output Measurement in the Services Sector. Chicago: The University of Chicago Press, 1992.

[9] K. Hart "Informal-Income Opportunities and Urban Employment in Ghana", The Journal of Modern African Studies, 1973, Vol. 11. №1.

[10] A. Henley, G.R. Arabsheibani, F.G. Carneiro "On Defining and Measuring the Informal Sector". Washington D.C.: The World Bank, 2006, World Bank Policy Research Working Paper, vol. 3866.

[11] R. Kapeliushnikov "Russia's human capital: what is its value?" Moscow: Publishing House of the Higher School of Economics, 2016

[12] OECD Productivity Manual. "A Guide to the Measurement of Industry Level and Aggregate Productivity Growth". Paris: OECD, 2001.

[13] S. Sassen "Informalization in advanced market economies", ILO Discussion Paper vol. 20, 1997. 